EGU21-8260, updated on 18 Jan 2022

https://doi.org/10.5194/egusphere-egu21-8260

EGU General Assembly 2021

(c) Author(s) 2022. This work is distributed under

the Creative Commons Attribution 4.0 License.

\title{
Formation of box canyons by mass failure in limestone: A modelling study of the role of groundwater seepage
}

\author{
Nader Saadatkhah ${ }^{1}$ and Aaron Micallef ${ }^{1,2}$ \\ ${ }^{1}$ GEOMAR Helmholtz Centre for Ocean Research Kiel, Dynamik des Ozeanbodens FE Marine Geodynamik, Germany \\ ${ }^{2}$ Marine Geology and Seafloor Surveying, Department of Geosciences, University of Malta, Msida, Malta \\ Groundwater seepage has been shown to unambiguously lead to channel formation \\ inunconsolidated sand to gravel sized sediments. However, its role in the evolution of \\ bedrocklandscapes remains controversial. In this study, we use the coastline of the Maltese \\ Islands as a case study to establish if and how groundwater seepage can form box canyons in \\ limestones. The study area comprises up to $40 \mathrm{~m}$ high coralline limestone cliffs, with a mean \\ fracturedensity of 1 in $5 \mathrm{~m}$, overlying a ductile marl layer. The permeability contrast promotes the \\ development of a perched aquifer and groundwater seepage at the cliff face. We ran numerical \\ simulations using a 3D distinct element model based on geological, geotechnical and hydrological \\ baseline information from the study state, and explored three potential mechanisms: (i) fracture \\ widening by fluid pressure and dissolution associated to groundwater flow and seepage, (ii) \\ fracture widening by loss of support at the base due tomarl displacement resulting from increased \\ water content, and (iii) a combination of (i) and (ii). We also took into consideration two scenarios: \\ (a) uniform groundwater seepage, and (b)focused groundwater seepage. Our results suggest that \\ the combination of mechanisms (iii) and the scenario with focused groundwater seepage (b) give \\ rise to the box canyonmorphology observed at the site. Box canyons thus initiate and grow via \\ detachment of limestone blocks and their toppling, which is more concentrated at the head where \\ groundwater seepage occurs.
}

